MATT ROBERTS

\title{
Copyright and Photocopying: an Experiment in Cooperation
}

The problem of copyright and photocopying by libraries is examined, with particular reference to the arguments offered by publishers in defense of the "exclusive right" provision of the copyright law. Proceeding step-by-step through these arguments, it appears rather that "fair use" is virtually self-explanatory and that libraries not only are privileged, but are obligated to photocopy reasonable parts of copyrighted works in order to fulfill their responsibility to scholarship and to "promote the Progress of Science and useful Arts."

$I_{N}$ N ONE OF HIS SEARCHING essays on the problems of copyright Luther Evans writes:

Copyright properly understood and wisely handled may be at the same time a powerful stimulus to creation and the means of opening the channels of dissemination of thought, information and debate. Misunderstood, and with its true purposes lost sight of, copyright can become a limitation on creation and a barrier to free exchange and expression. Like many other products of man's genius in the realms both of science and of law, it has a capacity for good or evil depending on his understanding and the use he makes of it. ${ }^{1}$

Librarians and publishers have been debating the problems of copyright and photoduplication for many years. Perhaps the most controversial question in the entire copyright debate has centered about the matter of "fair use"-that is, the manner in which librarians contend

\footnotetext{
${ }^{1}$ Luther H. Evans, "Copyright and the Public Interest," New York Public Library Bulletin, LIII (January 1949), 4.
}

Mr. Roberts is Chief, Circulation Department, John M. Olin Library, at Washington University, St. Louis. they are privileged to use copyrighted materials and publishers say they are not. Controversy in this one area has led librarians and publishers along widely diverging paths in search of a just solution.

"Fair use" is a difficult concept to define. In fact, if there is any agreement at all, it is that the term "eludes precise definition," 2 and yet many have attempted to define it. Fair use has been defined as "a doctrine which enables the courts to live with a law which contains a misstatement of fact so palpable that, if interpreted and enforced literally, it would involve them in absurdities contrary to the public interest"; ${ }^{3}$ as a "privilege in others than the owner of a copyright to use the copyrighted material in

\footnotetext{
${ }^{2}$ U.S., Congress. 87th Congress, 1st session. Copyright Law Revision. Report of the Register of Copyrights on the General Revision of the U.S. Copyright Law, July 1961 (Washington, D.C., U.S. Government Printing Office, 1961), p. 24.

${ }^{3}$ Verner W. Clapp, "Library Photocopying and Copyright: Recent Developments," in Law Library Bulletin, v. 55, February 1962, p. 12. The law to which Mr. Clapp refers is the 1909 Copyright Law. The "misstatement of fact" refers to that part of the law which states that the owner of the copyright "shall have the exclusive right to: print, reprint, publish, copy and vend the copyrighted work." It is this statement that has led to such bitter disagreement between librarians and publishers.
} 
a manner without his consent ..."; ${ }^{4}$ and as a type of limited license to publish, which appears to be inherent in the nature of statutory copyright. ${ }^{5}$ These and other definitions are all accurate in one sense or another, but they leave too much uncertainty as to what can or cannot be done in everyday practice. ${ }^{6}$ Perhaps the term eludes any definition whatsoever.

One purpose of this essay is to determine whether it is actually necessary to define "fair use" at all. It will be the contention of this paper that it is not. Were all irrelevant issues to be cleared away, and the principal arguments proceeded through systematically, it would be found that, in logic anyway, the term virtually defines itself. But before this may be done, one must accept two conditions. First, librarians must agree to be less contentious about their "rights" and accept the fact that publishers, too, have rights; and second, publishers must desist from their curious habit of waving the eighth commandment under librarians' noses, and understand that they are only attempting to fulfill their obligation to scholarship.

There are, it seems, but three basic issues involved in "fair use" in copyright and photocopying by libraries, and none is beyond compromise. They are: (1) Does "fair use" denote only single copies of a "reasonable part" 7 for private use, and in lieu of hand transcription, or does it include the reproduction of entire

\footnotetext{
${ }^{4}$ Horace G. Ball, The Law of Copyright and Literary Property (New York: Banks and Co., 1944), p. 260.

${ }^{5}$ Ralph R. Shaw, Literary Property in the United States (n.p.: Scarecrow Press, 1950), p. 67.

${ }^{6}$ Unlike the 1909 copyright law, the proposed copyright revision at least mentions "fair use," stating that ". . . the fair use of a copyrighted work is not an infringement of copyright." See: U.S., Congress. 89th Congress, 1st session, A Bill for the General Revision of the Copyright Law, Title 17 of the United States Code (Washington, D.C.: U.S. Government Printing Office, 1965), p. 17.

" 'Reasonable part' is another term which has never been defined to the satisfaction of all concerned. Let us say here, for the record, that a reasonable part would include one or more pages, but less than an entire chapter or journal article.
}

chapters or articles, or multiple copying for classroom (reserve) use, in lieu of purchase?; (2) Does copyright and "fair use" apply only to monographs, or to both monographs and serials?; and (3) Does it matter if the photocopying of a reasonable part is done gratis or at a charge?

Few would contend that libraries have the right to photocopy an entire copyrighted book, or a major portion thereof, because such copying would substantiate the publishers' argument that photocopying is an extension of printing, ${ }^{8}$ in lieu of purchase. But is this kind of reproduction really a threat to publishers' interests? The immediate question must be: Why would a library want to copy an entire book, or a substantial portion thereof? Reproducing a complete book, to which the library would have to add the cost of collating and binding, would be cumbersome and economically unfeasible. If it is a matter of replacing deteriorating books, a library would undoubtedly find it less expensive to seek the services of an organization specializing in reprinting and/or photocopying, and would get a better product. This is particularly true since all too frequently the library's copy will be in such poor condition that it cannot easily be copied, as will likely be the situation in other libraries owning that particular edition. Moreover, whole book copying for preservation for the most part involves books in the public domain. ${ }^{9}$ For these reasons, it is difficult to see how publishers are injured by this kind of copying.

\footnotetext{
8 "House Copyright Hearings: Education and Fair Use,' " in Publishers' Weekly, v. 188, no. 9, section 1, August 30,1965 , p. 291

W. S. Buddington, in his study of the use of copyrighted material, reports that only about 10 per cent of material copyrighted is renewed for the second twentyeight years. See: William S. Buddington, "Using Copyrighted Materials," in Special Libraries, LII (November 1961), 511. It is interesting to speculate on why, in view of this low renewal rate, publishers are so eager to see incorporated in the proposed copyright law that the term of copyright be the life of the author plus fifty years.
} 
But there are those who contend that photocopying per se is injurious to publishers, their writers, and, ultimately, the public. ${ }^{10}$ This position appears to be totally unacceptable. It is based on the general principle that all copying is in lieu of purchase, and this certainly is not the case. No library can expect a scholar (or any other reader) to copy several hundred or thousand words by hand, so that he might have for future reference the gist of another man's thinking. Single copy reproduction for private use, and in lieu of hand transcription, is and must be associated with the precept that only the manner of expression, and not ideas themselves, are protected by copyright. It would seem that no reasonable man could deny the logic of this.

The publisher who contends that copying is intrinsically in lieu of purchase has made a serious mistake. It is abundantly clear that the alternative is not between photocopying and purchase of another copy; it is between photocopying and copying by hand, memorizing, or, what is more likely, doing without. And whereas, if libraries reproduce single copies for scholars, publishers have not lost; indeed, they have gained, to the extent that new books may be forthcoming. But if libraries refuse to make single copies for private use, publishers have not gained even a little; and libraries have failed in one of their principal responsibilities, which is to assist the scholar and thereby "promote the Progress of Science and useful Arts." The scholar loses, and, presumably, scholarship suffers.

The area in which publishers, and particularly monograph publishers, should concentrate their efforts is in the copy-

\footnotetext{
${ }^{10}$ Roger H. Smith, "Library Photocopying: The Stalemate Deepens," in Publishers' Weekly, CLXXXIV (August 12, 1963), 41; and, again, in Benjamin Kaplin, "Copyright, Libraries, and the Public Interest," in College \& Research Libraries, XXI (May $1960), 215$.
}

ing of entire chapters or articles, and multiple copying, principally for classroom use, which, both in logic and in law, is clearly indefensible and deleterious to their interests. ${ }^{11}$ It is publishing, pure and simple. Unless permission is obtained in advance, there can be little justification for this kind of copying. ${ }^{12}$ There is a wide range of difference between one copy of ten pages for private use and ten copies of one page for public use. But one point must be crystal clear. The publisher who contends that there is no essential difference between reproducing ten copies for ten scholars over a period of time and ten copies at one time for "public" use is mistaken. In the former, copying is purely in lieu of hand transcription; in the latter, it is in lieu of purchase. Unfortunately, there are librarians as well as publishers who fail to see the distinction.

In the early days of the "fair use" controversy, librarians and publishers did agree informally to allow singlecopy reproduction for private use. The "Gentlemen's Agreement" of 1935 stipulated that a library could make a single copy of a copyrighted work for a scholar who stated in writing that he desired such reproduction in lieu of loan of such publication or in place of manual transcription, and solely for the purpose of research. ${ }^{13}$ The original agreement

\footnotetext{
${ }^{11}$ Curtis G. Benjamin, "Book Publishers' Interests in Reprographic Copyright," in Library Journal, LXXXVIII (August 1963), 2840.

${ }^{12}$ Photocopying entire chapters or journal articles, particularly the latter, for inter-library loan purposes is pertinent here, in that it involves more than a "reasonable part." While it could be argued that such copying is for private use and in lieu of lending, it could just as easily be argued that it is for private use but in lieu of purchase. Perhaps if specific pages to be copied could be specified, this might be resolved; but it is difficult to specify pages before the "loan" is made. Nevertheless, a library might find it difficult to demonstrate that photocopying an entire journal article for inter-library loan constitutes "fair use." This assumes, of course, that the article is copyrighted.

13 "The Gentlemen's Agreement and the Problem of Copyright," in Journal of Documentary Reproduction, II, 29-36.
} 
was between the Joint Committee on the Reproduction of Materials for Research and the National Association of Book Publishers. It was later used as a basis for ALA's Materials Reproduction Code. While the agreement still serves as a guide to some libraries, faith in the Gentlemen's Agreement and strict adherence to the single copy principle apparently has fallen by the wayside. ${ }^{14}$

It fell in part because librarians considered it unsatisfactory for several reasons, mainly because it implied an admission on the part of librarians of a violation of the law which publishers were willing to overlook ${ }^{15}$-a license to steal, so to speak. In one sense this was an unfortunate attitude. It is possible that publishers might have continued to subscribe to the single-copy concept had librarians been willing to adhere to it in practice, if not in theory, and had they instituted an effective program to prevent multiple copying. But they did not. Today, publishers, as well as librarians, know all too well that an increasing number of libraries are producing multiple copies of chapters and journal articles for use in reserve reading rooms; consequently, it is not surprising that many publishers are deeply concerned over the practice of photocopying in general.

Is there any distinction between copyright of a monograph and of a periodical? The present copyright law requires the author, or, in the event of transfer of right, his agent (publisher) to apply

\footnotetext{
${ }^{14}$ Edward G. Freehafer, "Photocopying and Fair Use," in College \& Research Libraries, XXI (May $1960), 217$.

${ }^{15}$ Edward G. Freehafer, "Summary Statement of Policy of the Joint Libraries Committee on Fair Use in Photocopying," in Special Libraries, LV (February $1964)$ p. 104. On page 105 of this article, the committee recommends that "it be library policy to fill an order for a single photocopy of any published work or any part thereof. Before making a copy of an entire work, a library should make an effort by consulting standard sources to determine whether or not a copy is available through normal trade channels." Publishers have not demonstrated much enthusiasm for this policy.
}

for copyright, deposit two copies of the best edition of the work with the Office of Copyright (Library of Congress), and to display the copyright notice on the title page or the page following. And this is about all that is required. This seems straightforward enough, at least for monographs, or any other form of one-time publication. But how does it apply to periodicals? Are individual articles in an issue covered? The author of a particular article may apply for and receive copyright protection (he need send in only one copy), or he may expressly assign his right to the publisher. But suppose he does neither? To those not versed in the law, section three of the 1909 act would seem at first to include periodical articles. In brief, it states that "copyright . . . shall protect all the copyrightable component parts of the work copyrighted." But then it goes on to say, "and all matter therein in which copyright is already subsisting. ... The copyright upon composite works or periodicals shall give to the proprietor thereof all the rights in respect thereto which he would have if each part were individually copyrighted. . .."16 (Italics mine). This is confusing. They are protected, but apparently only if copyright already subsists. Perhaps if the wording had been "as if," it might have been construed to mean the individual articles. Out of the confusion has come the interpretation that the copyright of an issue does not protect the individual articles, unless: 1) rights are assigned to the publisher; or 2) the publisher or one of his employees is the author of the article. $^{17}$

${ }^{16}$ U.S., Congress. 60th Congress, 2nd session. Congressional Record, XLIII (Washington, D.C.: U.S. Government Printing Office, 1909), 3701-3702.

${ }^{17}$ U.S., Congress. 86th Congress, 2nd session. Copyright Law Revision. Studies Prepared for the Subcommittee on Patents, Trademarks, and Copyrights of the Committee on the Judiciary United States Senate, 86 th Congress, 2 nd session, pursuant to S. Res. 240, studies 11-13, (Washington, D.C.: U.S. Government Printing Office, 1960), p. 18. 
The proposed copyright law revision, unless the revision is revised, clarifies the old law, and excludes individual contributions, stating that,

. . . copyright in each separate contribution to a collective work is distinct from copyright in the collective work as a whole, and vests initially in the author of the contribution. In the absence of an express transfer . . . the owner of copyright in the collective work is presumed to have acquired only the privilege of reproducing and distributing the contribution as part of that particular collective work. . . . ${ }^{18}$

Individual articles, then, are not and will not be protected by copyright, unless the author expressly transfers his right, and very few do so at this time. ${ }^{19}$ Some may be protected, however; and the library that copies articles freely may be infringing. Aside from this possibility, if the library requires copies of complete articles for whatever purpose, it can and should ask for permission in advance (see Appendix).

Is there actually any real difference between reproducing a single photocopy for a scholar gratis and doing the same thing at a charge? Do libraries have the right to install (or have installed) coinoperated copiers? Does it matter that the library receives no income from public copiers and may even lose money in the copying it does for scholars? There seems to be little agreement among librarians and publishers in these admittedly difficult aspects of photocopying.

From the publishers' side, the essential point seems to be that in making a copy for a scholar, the library is not copying for itself, but for another party; and, even if it loses money in the operation, the fact that it charges for the work is the real distinction. ${ }^{20}$

The publishers' argument in essence

${ }^{18}$ U.S., Congress. 89th Congress, 1st session, op. cit., p. 12 .

${ }^{19}$ U.S., Congress. 86th Congress, 2nd session, op. cit., p. 18 .

${ }^{20}$ Miles O. Price, "Photocopying by Libraries and Copyright: a Precis," in Library Trends. VIII (January $1960), 438$. seems to be that in copying for another and for compensation, the library deprives publishers of income which they, the publishers, would receive if the $i$ brary did not copy. It is again the "in lieu of purchase" argument, and, insofar as it presumes that if the library did not copy, the publisher would (i.e., print), it is tenuous logic. While in a sense the "for compensation" and "copying for another" principles are the best arguments publishers have against photocopying bv libraries, they are valid only in an unrealistic sense, for when the logic is carried one step further-i.e., in lieu of purchase-it just does not hold up, because photocopying for private use is not in lieu of purchase, but in lieu of manual transcription.

The solution to this problem is for libraries to demonstrate beyond question that: a) single photocopies are solely in lieu of manual transcription; and b) no profit is realized from photocopying. They have, it would appear, demonstrated the former, and they can demonstrate the latter. They must do so, because there can be no justification in a library deriving profit from photocopying. Fulfillment of these prerequisites would place libraries on safe ground in the spirit, if not the letter, of the law.

When one comes to the question of coin-operated copiers, he is really in a forest of terrors, both real and imaginary. Publishers can at times be quite vehement in their opposition to public copiers, contending that unsupervised copying cannot in any sense be called "fair use." 21 One can only suppose they presume all such copying to involve copyrighted materials. But librarians too can be equally adamant in the opposite direction. ${ }^{22}$ (One begins to suspect that Armageddon may be more appealing to

${ }^{21}$ Lee C. Deighton, "Books, Not Copying Machines, Are the Long-term Answer," in Library Journal, XC (May 1, 1965), 2090.

${ }^{2}$ Charles F. Gosnell, "The Copying Grab-bag, Observations on the New Copyright Legislation," in ALA Bulletin, LX (January 1966), 50. 
many than the market place of reason. It is probably more exciting, anyway!)

From both points of view, the problem here is largely, but not entirely, economic. The coin copier is valuable to the library in several respects: (1) in copying personal materials, e.g., lecture notes; (2) in relieving the library in part of the considerable staff costs involved in providing copies; (3) in providing copying services when the library's copying section is closed; and (4) in alleviating to some extent the serious problem of mutilation.

The argument against public copiers is that the library has no control over the use made of them. This is a valid argument, but only if one assumes that they are used for copying copyrighted materials in lieu of purchase; without this assumption it is no argument at all. Let us, then, consider the possible uses that can be made of such copiers: a) they are used to copy personal materials or works now in the public domain; b) they are used to reproduce single copies of a reasonable part for private use and in lieu of hand transcription; c) they are used to copy entire chapters or journal articles, or to make multiple copies for public use, in lieu of purchase. Use "a" presents no problem; "b" should not be a problem; and "c" would constitute infringement.

But are public copiers used for purposes such as in "c"? To believe that anyone is going to deposit dime after dime, or quarter after quarter, in a machine in order to copy an entire chapter or article solely in lieu of purchase, or to make multiple copies for public use, calls for an imagination of some vividness. It could be done, of course, and publishers are theoretically correct; but in all likelihood they are frightened by a chimera.

The third party in all this-the manufacturers and distributors of copying devices-who reap, as it is said, where they do not sow-should be the ones to reimburse publishers for any income actually lost. Unfortunately, no workable method has been devised to implement such a system.

The problems involved in compensating publishers for income lost, if in truth any is, because of library photocopying are all but insoluble. ${ }^{23}$ But the problem can doubtless be solved, and, at the same time, the entire issue of "fair use" summarized, by means of a series of questions and answers.

Q. Can libraries justify photocopying in lieu of purchase?

A. ... They cannot.

Q. If publishers actually do lose income, would the cost to libraries and publishers alike in collecting and distributing penny royalties exceed the amount collected?

A. .... Very likely.

Q. If income is lost, as publishers insist, which publishers lose and how much?

A. ... No one knows.

Q. Assuming that photocopies are produced solely in lieu of hand transcription, how much copying, either by the library directly, or by means of coin-operated copiers, involves copyrighted materials?

A. ... No one knows.

Q. Considering only the reproduction of copyrighted materials, how much income is lost?

A. ... No one knows.

Q. Do publishers really lose any income at all because of photoreproduction of copyrighted materials?

A. .... No one knows.

Q. If we assume that libraries agree to forego all photocopying, is it then reasonable to expect publishers to keep on hand an adequate number

${ }^{23}$ Solutions have been offered, however; some of them quite bizarre. See, for example: U.S., Congress. 76th Congress, 3rd session. Congressional Record, LXXXVI (January 3, 1940) 65-66; and "A Licensing System, A Proposal by the Authors League of America, Inc.," in Library Journal, XCI (February 15, 1966), 892-93. 
of copies of each individual work, including journal articles, to satisfy demand for the life of the copyright?

A. ... It is not.

Q. Do publishers have any obligation to provide copies on demand for the life of the copyright?

A. ... In a limited sense, they do not, as the copyright law stipulates only that two copies of the work to be copyrighted be deposited with the Register of Copyrights, and does not require that even one copy be offered for sale to the public. But in a much broader sense, they do, because publishers, as well as librarians, are obligated to "promote the Progress of Science and useful Arts." This is no mere moralistic viewpoint, but a serious and unavoidable obligation on the part of publishers-it represents the Constitutional basis of all copyright legislation in the United States. The Constitution states that "The Congress shall have the power... To promote the Progress of Science and useful Arts, by securing for limited Times to Authors and Inventors the exclusive Right to their respective Writings and Discoveries." (Art. 1, Sec. 1 (Par. 8)) And while the publishers who oppose photocopying have been quick to seize upon the "exclusive right" concept, they have seemingly been less aware of their responsibilities concerning the promotion of science, etc. They have taken the ideas of "progress" and "exclusive right" and made them their own; and, in doing so, they have failed to see that no "exclusive right" can remove from them the responsibility to scholarship which the Constitution intended and which librarians must assume.

It follows then that: 1) publishers should accept fully a policy of single photocopies of a reasonable part of any copyrighted work for private use, in lieu of hand transcription; and 2) librarians, under the positive leadership of the association, should agree that, unless permission is obtained in advance, reproduction of entire chapters and complete articles, and multiple copying for public use, will not be permitted.

\section{APPENDIX}

The faculty of a university frequently calls upon the library to provide multiple copies of books and periodical articles for class (reserve) use. Books represent here only a limited problem, as they can usually be obtained in sufficient quantities. In addition, the use-turnover of books is usually considerably lower than that of journal articles. Periodical issues, particularly retrospective issues, are a problem, as they are not available very long, or long enough, after publication; and, even if they are, it is usually at a relatively high price. The library therefore finds itself in a dilemma. It must provide the necessary materials, and yet, short of photocopying, it finds it difficult to do so.

The problem essentially is one of time, and to a lesser extent of cost. Admittedly, given sufficient time, the library might be able to find added copies of back issues, though as stated above at considerable cost. Also it might discover that reprints are available. Finally the library might be able to obtain permission from publishers to make multiple copies of specified articles. Often, however, there is too little time to make effective use of these alternatives. What then can the library do? If the solution does not lie in multiple subscriptions, because of cost; nor in specific requests to copy, because of time; the library must look elsewhere. That it must do something is obvious, for if it elects to do nothing, it merely passes the problem, and solution, on to someone else.

A three-way attack on the problem is possible. The library might increase the number of its subscriptions to major periodical titles. This need not be done solely as a solution to the reserve problem, but to provide added copies of materials which are in great demand for research. It might 
also subscribe to reprints (e.g., Bobbs-Merrill) in one or more copies. Finally, it might request permission in advance from publishers whose periodicals are considered essential for reserve use.

With this final approach in mind, the author contacted the publishers of 255 periodicals, requesting permission to make up to five copies of single articles for reserve use. The library agreed to pay a reasonable royalty, if required, and gave assurances that the copies would not be given away or sold, and would be destroyed when the need for them had passed. At the same time, the library took out second and even third subscriptions of frequently used journals and expanded its coverage of reprints.

Replies were received from 227 of the 255 publishers contacted. Some 117 (45 per cent) agreed to permit multiple copy- ing as specified and did not demand royalties or attach any contingencies; forty-four (17 per cent) granted permission without royalty but did attach certain conditions, such as source on each copy, informing the publisher as to what was copied, sending one copy to the publisher, and returning copies when no longer needed. Nineteen ( 7 per cent) granted permission with royalty and, in several cases, wished to be informed of what was copied. Thirtysix (14 per cent) reported either that their authors held copyright, or that their policy did not permit copying. The remaining four ( 1 per cent) reported they had a reprint arrangement and therefore could not permit copying. In summary, 183 (72 per cent) extended overall permission, forty (16 per cent) refused permission, and thirty-two (12 per cent) did not reply.

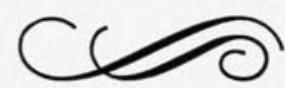

